\title{
Constructing Human Rights Justiciability in Human Rights Courts in Indonesia
}

\author{
Firdaus $^{1, *}$ Oksimana Darmawan ${ }^{1}$ Yuliana Primawardani ${ }^{1}$
}

\author{
${ }^{I}$ The Agency for Research and Development of Law and Human Rights of the Ministry of Law and Human Rights of The \\ Republic of Indonesia, Jakarta, Indonesia \\ *Corresponding author. Email: firdausamir66@gmail.com
}

\begin{abstract}
In Indonesia, human rights courts are ad hoc and are only intended for serious human rights courts. This means that there is no special human rights court that deals with the justiciability of human rights, particularly the justiciability for the fulfillment of limited economic, social and cultural rights. This condition is different from civil and political rights which have the principle of non-derogable rights. The research question is how the implementation of human rights justiciability in Indonesia and several other countries in order to build the construction of human rights justiciability in human rights courts in Indonesia. This paper uses the normative juridical as a research method. The results showed that Indonesia already has regulations on the justiciability of the rights to health, education and work which are part of economic, social and cultural rights. In practice, cases of violation of economic, social and cultural rights are often linked to civil and even criminal cases. In addition, the human rights court mechanism is more inclined towards a constitutional court within the authority of the Constitutional Court, because providing remedies cannot be done at the Supreme Court. Countries that have human rights courts under the Constitutional Court include South Africa, Germany, Spain, South Korea, Azerbaijan, Bavaria and Croatia. Meanwhile, countries that regulate remedies through the Supreme Court include the United States, Canada and Japan. Therefore, it is recommended to make material changes in the Human Rights Law, including changes to the definition of human rights violations, the definition of human rights justiciability, and human rights courts in the Constitutional Court.
\end{abstract}

Keywords: justisiability, human rights violations, human rights court, remedy, the constitutional court and the supreme court.

\section{INTRODUCTION}

Indonesia is a constitutional state that seeks to provide protection for its citizens through laws and regulations. With the existence of sanctions set out in the applicable regulations, it is hoped that it can minimize the number of criminal acts in Indonesia, including those that lead to human rights violations. In this case, in 2019 National Human Rights Commission received 3,084 complaint files which were followed up by handling cases. This number consists of 2,049 new cases and 1,035 follow-up cases. A total of 2,757 cases were received by the National Human Rights Commission in Jakarta, and 327 cases were received through the representative offices of the National Human Rights Commission. In the 3,084 complaint files that were complained of, the Monitoring and Investigation Division received
954 cases, consisting of 424 new cases and 530 follow-up cases to be further handled by the respective monitoring and investigation report staff. The cases handled by the Monitoring and Investigation Division are then referred to as handling cases of human rights violations, especially among marginalized and vulnerable communities. [1]

The data is one form of complaint made by the public to the National Human Rights Commission. Until now, many people still consider that human rights violations are violations of the right to life with the disappearance of lives or crimes against humanity that lead to serious human rights violations. In this case, Law No. 26 of 2000 concerning human rights courts has regulated human rights courts for human rights violation, but still 
limited to gross human rights violations, both current and past gross human rights violations with ad hoc human rights court mechanisms. This means that the human rights court set up in Indonesia is a "special court against severe human rights violations," [2] and there is no human rights court yet to regulate the resolution of human rights violations as the understanding of human rights violations in Article 1 Number 6 of Law No. 39 of 1999 on human rights, as follows:

"A violation of human rights is the conduct of a person or group of persons including state apparatus either intentional or inadvertent or negligence that unlawfully reduces, impedes, restricts, and or revokes the human rights of a person or group of persons guaranteed by this Act, and does not obtain, or is feared not to obtain a fair and correct legal settlement under the applicable legal mechanisms".

The development of human rights arrangements through regulation in Indonesia is rapid, among others, Indonesia has ratified the International Covenant on Economic, Social and Cultural Rights through Law No. 11 of 2005 and ratified the International Covenant on Civil and Political Rights through Law No.. 12, 2005.

Civil and political rights include all rights that protect individuals against physical security violations with arbitrary executions, torture, and cruel, degrading or inhuman treatment or punishment. Civil and political rights also protect citizens from persecution by state officials through confessions before the law, prejudice of innocence, guarantees of a fair and impartial open trial, prohibition of retroactive regulations, and protection against arrest, arbitrary detention or exile abroad. The right to citizenship and owning a home in a country is also protected by the right to nationality, freedom of movement, and choice of residence.

The rights that exist in the Convention on Civil and Political Rights can be grouped into two, namely non-derogable and derogable rights. Non-derogable rights are absolute that should not be mitigated by the state even in an emergency. The rights included in this type are: Right to life; The right to be free from torture, the right to be free from slavery, the right to freedom from detention for failing to fulfill the covenant (debt); the right to be free from retroactive funding: the right to be the subject of law; and the right to freedom of thought, belief and religion. When violations of non-derogable rights are committed by the state, that the country will be considered to have committed a serious violation of human rights.

The Economic, social and cultural rights have a wider scope, so the government also establishes various other laws and regulations as a follow-up to the ratification made to the International Covenant on Civil and Political Rights, among others, Law No. 35/2014 on Changes to Law No. 23/2002 on Child Protection, Law No. 14/2008 on Disclosure of Public Information, Law No. 19/2016 on Changes to Law No. 11 of 2008 on Electronic Information and Transactions; Law No. 5 of 2017 on Cultural Promoting, and a number of other related laws, even the Constitution of the Republic of Indonesia underwent amendments four times (1999, 2000, 2001, and 2002) which in the second amendment, among others listed various basic norms in the field of human rights in Article 28A up to Article 28J.

Furthermore, the absence of a human rights court indicates that the material of other human rights violations has not received the attention of the Indonesian government as much as attention to gross human rights violations. Regarding the material of other human rights violations, as regulated in Law no. 39 of 1999 concerning Human Rights (hereinafter referred to as the Human Rights Law) which consists of 10 groups of rights, both in the form of themes and subjects, namely the right to life; right to have a family and continue the offspring; the right to self-development; right to justice; the right to personal freedom; the right to security; right to welfare; and the right to participate in government; women's rights; and children's rights.

This condition is considered very concerning, given the human rights issues related to various aspects of life as well as the classification of human rights in the human rights law, so that the State has an obligation to respect, protect and fulfill human rights. The obligation to respect means that the state must refrain from intervening against guaranteed rights or refraining from restricting the exercise of rights in the event that restrictions on such rights are expressly not permitted. The obligation to guarantee is ensure a positive duty that contains two types of obligations, namely the obligation to protect and the obligation to fulfill. The obligation to protect is the obligation of the state to provide protection, including protecting the right from the intervention of non-state actors (private interfrance). This includes the obligation of the state to take necessary measures, such as preventing actions that are deemed to threaten the exercise of rights or condemning the transgressions. If the country does 
not perform its obligations, then the country can be said to commit human rights violations. This violation occurs because the state fails to fulfill its obligations to protect the rights (human rights) guaranteed in international and national law, either because it intentionally did so (commission), or performed omission. [3]

In addition, based on the results of the International Law Commission study, referring to the International Covenant on Economic, Social and Cultural Rights, it is mentioned that the obligation of the state has two combinations, between obligation of conduct and obligation of result.[4] The division of these types of obligations to which rights groups are part becomes relative and difficult to separate, sometimes there is one right in civil and political rights groups that requires a pattern of implementation to fulfill economic, social and cultural rights. The implementation of human rights related to the division between types of rights on the one hand and the obligations of the state on the other is intended to make it easier to understand that in all types of rights, as well as rights that are specific in nature, that the state is basically the party that bears the obligations, so that in the end it is more flexible with assess the fulfillment of these rights in terms of state obligations towards the result. [5]

The state's obligations in the prevention and handling of human rights violations are also related to justiciability. In the Black's Law Dictionary, justiciability is the quality of being appropriate for review by a court, [6] justiciability as a quality (an issue) to be examined (or prosecuted) by a judicial institution. As for this study, human rights justiciability is related to civil and political rights as well as economic, social and cultural rights.

The justiciability of civil and political rights is absolute, because it is free of charge, as is the case in the justice system which is related to the protection from criminal law, the right to an honest trial, equal recognition before the law, and the right to be free from torture; while the fulfillment of economic, social and cultural rights is limited, because there is financing in its fulfillment, so that economic, social and cultural rights demands are impediment in its fulfillment. This obstacle is realized because the application of economic, social and cultural rights is not likely to be presented to the court if this right is violated (non-justiciable), because the application of economic, social and cultural rights is a political issue, namely the rights to work, health, food, clothing, housing, and education are considered as state policy programs in the field of economic, social and cultural rights. In this case, the application of economic, social and cultural rights is not yet considered a human rights issue. This argument is reinforced by the absence of an international mechanism to demand justice for violations of economic, social and cultural rights.[7] This condition is one of the reasons there is no mechanism for law suits and complaints in the event of human rights violations in Indonesia, so the human rights court is not currently able to determine this.

Based on the above background, the basic conception of this research is that although the application of economic, social and cultural rights is a political issue that is considered a state policy, it does not rule out the state's policy to violate economic, social and cultural rights, so the state's efforts on the obligation of conduct and obligations on the result should be realized according to the state's capacity, because the justiciability for fulfilling Civil and Political rights is not always free of charge, even the costs incurred are very large, as in the practice of regional head election disputes in the Indonesian Constitutional Court which decided to hold a re-election of regional heads. Therefore, the question of this research is how to implement the justifiability of human rights in Indonesia and several other countries in order to build the construction of human rights justiciability in human rights courts in Indonesia.

\section{RESEARCH METHOD}

This research uses normative juridical methods conducted through library studies that study secondary legal materials in the form of legislation or other legal documents, and secondary data in the form of research results or other references. [8]

The data obtained will be analyzed in depth qualitatively in order to build the construction of human rights justification in human rights courts in Indonesia.

\section{FINDINGS AND DISCUSSION}

\subsection{Implementation of Human Rights justiciability in Indonesia}

In Indonesia, the Human Rights Court is one of the special courts within the General Courts under the Supreme Court and is dedicated to cases of gross human rights violations, most of which are violations of the civil rights of citizens. However, not all types of civil rights violations are categorized 
as gross human rights violations, so not all of them can be resolved through the current Human Rights Court. In this case, economic, social and cultural rights are the rights of a person who should receive the same attention as civil and political rights, considering that there is no prosecution mechanism for these neglected or violated rights.

According to research results from Agency for Research and Development of Law and Human Rights in 2018, it is known that the fulfillment of the justifiability of the economic, social and cultural rights which are the responsibility of the State is still experiencing obstacles and shortcomings, so that people do not get these rights and need a mechanism to claim these rights. One of the field findings related to Justiciability of the Right to health, shows that there are still deficiencies in some hospitals related to their services, facilities, including infrastructure and facilities, so that the community complains about this to the Provincial Representative Ombudsman. [9]

These conditions indicate that the right to health has not been properly fulfilled when referring to General Comment 14 on the Right to the Highest Standard of Health which can be reached in the Committee on Economic, Social and Cultural Rights, (Session 22. Geneva, agenda 3: 3. Implementation The International Covenant on Economic, Social and Cultural Rights) states that the right to health in all its forms and at all levels contains important and related elements. The appropriate application will depend very much on certain conditions in a particular country, namely first, availability means that the implementation of public health functions and health service facilities, health goods and services, as well as programs, must be available in sufficient quantity at one time. Country. Second, accessibility, namely health facilities, goods and services, must be accessible to everyone without discrimination, within the jurisdiction of the State. Third, acceptance, that is, all health facilities, goods and services must be accepted by medical ethics and culturally appropriate, for example respecting the culture of individuals, minorities, groups and society, sensitive to gender and life cycle requirements. Fourth, quality, apart from being culturally acceptable, health facilities, goods and services must be scientifically and medically appropriate and in good quality. [10]

With regard to the Justiciability of the Right to Education which reveals that the court processes more the fulfillment of people's Education rights related to the misappropriation of Student Operational Assistance funds or the violence that occurs in schools committed by teachers, thus leading to more civil rights protections. Meanwhile, those reported to the Ombudsman or nongovernmental organizations are more likely to be unfair to educational institutions in the process of accepting students in the online system as a result of regional and remote conditions, resulting in delays in filing. [9]

Other field findings on the Justiciability of the Right to work, there are protections for workers' rights that need to be looked at from several aspects that include guarantees against right to work, workers' rights including to earn a fair wage, union rights that have not been covered. Various violence as well as other forms of modern slavery or human trafficking practices still occur. Referring to some of these things, the findings of the field show that the District Court adopted the mechanism through the Industrial Relations Tribunal which was previously settled by the Arbitral Institution of the Ministry of Manpower. This is done for alternative resolution of problems between workers and companies as well as the government, so that it can be resolved without having to go to court. But if it is not resolved, it will proceed to court. In addition, the community also raises objections or injustices in the company's work to NGOs/Legal Aid. [9]

The three field findings indicate that there is no court that has the authority to specifically adjudicate human rights violations, both civil and political rights as well as economic, social and cultural rights (economic, social and cultural rights), and also as a form of legal responsibility in the provisions on the definition of human rights violations Article 1 Number 6 Law Number 39 Year 1999 concerning Human Rights. The context of human rights justiciability is still partial, namely the serious human rights court is tried in the General Court, the administrative sector is tried at the State Administrative Court, labor is tried at the Industrial Relations Court, and the product of legislation is tested under statutory law in the Supreme Court, while the examination laws with the constitution are tried in the Constitutional Court.

\subsection{Implementation of Human Rights Justiciability in Several Countries}

In the United States, the human rights justiciability mechanism is through the Supreme Court. The United States does not need an independent body or institution outside the Ordinary 
Law Courts, with the top of its hierarchical structure being the Supreme Court, which has the authority to provide judicial review of laws against its constitution including human rights violations caused by law ( for example, there is material that is discriminatory) until the award of a remedy (restoration) decision. This means that the Supreme Court guarantees remedies, if human rights violations have been proven.[11]

In Canada, the country's constitution is known as the Canadian Charter of Rights and Freedom, which is enforced by the Supreme Court. In the Charter there is a power of remedy. [12]The terms of repair are found in s. 24 (1) and 24 (2).

S 24 (1) stated that "Is the general remedial provision which is 'appropriate and just in the circumtances.".[12]"S. 24 (2) stated that "Is a specific remedial provision which provides for the exclusion of evidence obtained in contravention of the Charter in some circumtances"..

In provision s. 52 (1) applies to laws found to be unconstitutional. There are five different solutions available in s. 52 (1) conditions, namely:

"Striking down the legislation; severing the offending provision; striking down or severance coupled with a temporary suspension of the declaration of invalidity; reading down the offending provision; and reading in an appropriate provision." [12]

Regarding Japan, in its development, the Japanese government has made efforts to improve its constitution, including the Kanoe proposal and the Matsumotho Draft. Dr. Soichi Sasaki of the Kyoto Imperial university who drafted Konoe's proposal, advocated for the establishment of a constitutional court and a constitutional review. Until finally, the Japanese Constitution of 1946 was enacted on November 3, 1946. Article 81 of the Japanese Constitution states that

"The Supreme Court is the court of last resort with power to determine the constitutionality of any law, order regulation or official act" and explicitly provides for constitutional review by the judiciary. [13]

Th Japan's constitution governs the Supreme Court to bring the courts under it to the same status as the government structure. The power of Supreme Court are not only for civil and criminal cases but for administrative cases. As a result of these structural changes, the newly formed Supreme Court bore a much greater burden in terms of the quality and quantity of cases compared to the Grand Court of Judicature, the highest court of law under the Imperial Constitution. [13]

The Supreme Court has succeeded in making two specific remedial actions to remedy unconstitutional conditions. First, litigation to cancel "malpractice" in the allocation of seats (malapportionment) House of people's representatives. In this case, the Court makes a formula that is the same as a court decision, ruling that the allocation of House of people's representatives seats for certain areas is unconstitutional, but at the same time, states that the holding of elections is still valid (used the doctrine of circumstantial judgment). Second, the Supreme Court has also interpreted Article 37 paragraph 1 of the Japanese Constitution, which guarantees the right to a speed trial which gives the courts the authority to shorten the trial process as a special measure on an ad hoc basis when certain criminal cases are postponed indefinitely, because it is assumed that it's hard to do a quick trial. [13]

Thus, in general, the systems for fulfilling the right of justifiability in the three countries, namely the United States, Canada and Japan are the same. The system of the three countries is different from Indonesia in that there is a separation of judicial authority (Supreme Court and the Constitutional Court), while the three countries have the structure of the judicial framework into one unit in the Supreme Court called the Supreme Court. The Supreme Courts in these three countries have the authority to adjudicate criminal, civil and administrative cases, including adjudicating or examining the constitutionality of legislation, even guaranteeing the fulfillment of the right to remedy (restoration or improvement). In this context, the three countries have implemented the fulfillment of the right to justify human rights, meaning that there is a judicial power that guarantees remedies for their citizens if the rights of citizens are violated against the provisions of constitutionality, in which human rights are part of constitutional provisions.

In Australia, the Supreme Court is called the High Court as the highest court. The similarity between the Australian High Court and the Supreme Court in the three countries (Japan, Canada and the United States) is that they do not have a Constitutional Court. However, the difference is that the High Court in Australia does not have the authority to decide on remedies for victims of violations of constitutional rights. [11] Although the High Court in Australia does not decide on remedies, 
courts in Australia cover violations of constitutional, administrative and legislative rights before the High Court or Tribunal Court.[14]

In contrast to Austria, which has a judicial power division, where the system of judicial power sharing is almost the same as Indonesia, namely the existence of a Supreme Court and a Constitutional Court (the United States, Canada, Japan, and Australia do not have a Constitutional Court). The difference is that the Constitutional Court in Australia provides remedies, for example placing remedies, namely the element "... other legal remedies are no longer available ..." as one of the conditions for judging the constitutionality of a law. [15]

In Germany, when constitutional rights are violated, the complaint mechanism through the Constitutional Complaint in the Constitutional Court is the same as for South Africa and Spain. A wellknown case, when the Muslim community in Germany submitted a request for constitutional complaint because of the prohibition against slaughtering animals based on the Animal Protection Law. The Muslim community objected to the prohibition because it was considered to be against the freedom to practice religion. Islamic teaching requires that animals be slaughtered before they are allowed to eat. The Federal Constitutional Court granted the application on the grounds that freedom of religion is guaranteed by the constitution. Meanwhile, the prohibition on slaughtering animals is only regulated under the constitution. Apart from Germany, a number of other countries that also implement a constitutional court include South Africa, South Korea, Azerbaijan, Bavaria, and Croatia. [16] This includes remedies, and even complaints of violated constitutional rights not only through law, but concerning statutory regulations under law.

This is different from the authority of the Constitutional Court in Indonesia, which is only in the judicial review of the product of legislation against the constitution, while the examination of statutory regulations under law is the authority of the Supreme Court. Whereas violations of the constitutional rights of citizens can not only occur through laws, but also through statutory regulations under law. [17] This is different from the authority of the Constitutional Court in Indonesia, which is only in the judicial review of the product of legislation against the constitution, while the examination of statutory regulations under law is the authority of the Supreme Court. Whereas violations of the constitutional rights of citizens can not only occur through laws, but also through statutory regulations under law.

Furthermore, in South Africa, the 1996 South African Constitution regulates civil and political rights as well as economic and social rights as rights that can be directly tried in the Human Rights Statement.[18] It can be said that its fulfillment must be facilitated by the state including the economic, social and cultural rights which are declared as justiciable rights in South African law, this right becomes a binding constitutional right to ensure protection and fulfillment through a mechanism of judicial remedies for everyone when their rights are not fulfilled. [19]

This mechanism is seen in the decision of the South African Constitutional Court regarding the Grootboom case regarding the right to adequate housing and submitted to the court to assess the constitutional compatibility of housing policies implemented by the government. The Court ruled that the eviction of a group of homeless people from their informal settlements without the provision of suitable standard temporary shelters was unwarranted and unconstitutional. Article 26 (1) of this constitution provides that everyone has the right to have access to adequate housing. Therefore, the court ruled that the government had failed to make adequate supplies for homeless people. [20]

Courts can also encourage legislators to act to realize social and economic rights while at the same time respecting the most appropriate methods of advancing those rights that legislators choose; can provide appropriate remedies to prevent or compensate for the arbitrary eviction of persons from their homes or the improper termination of the provision of social security benefits; and order the Minister of Corrections and other prosecuted parties to provide anti-viral drugs to HIV positive applicants by fulfilling their right to be provided with 'adequate health care' at state expense. [18]

Another case related to the capacity of the South African state budget, in which the court ruled that the applicant demanded to receive dialysis kidney care in a government hospital was not covered by the right to "emergency health care" covered under section 27 (3) of the South African Constitution. In considering these charges, the court indicated that broad limits on discretion would be placed on priority arrangements relating to budgets by the provincial government and hospital administrators 'difficult decisions' of limited resources. [18] 


\section{Conception of Human Rights Justiciability Construction into The Indonesian Human Rights Court}

The conception of the construction of human rights justifiability into the Indonesian Human Rights Court is carried out by discussing a number of laws to the authority of state institutions.

Regarding the right to justice (justiciability), in Article 17 of the Human Rights Act stated, that:

"Every person without discrimination, has the right to obtain justice by submitting a petition. complaints and lawsuits, both in criminal, civil and administrative cases and are tried through a free and impartial judicial process, in accordance with the procedural law which guarantees an objective examination by an honest and fair judge to obtain a fair and correct decision ".

The phrase in the provision of the right to justice in the Human Rights Law does not state clearly or clearly related to claims and complaints of rights, both in the fields of Civil and Political rights as well as the rights of Social, Social and Political Sciences, although implicitly complaints and challenges are included in this right, but they need to be included. in Article 17 of the Human Rights Law related to 'complaint phrases covering Civil and Political rights and the rights of Social, Social and Cultural Affairs'. This is because the classification of these two areas of right has received recognition by the state through the ratification of the International Covenant on Civil and Political Rights and the International Covenant on Economic, social and cultural rights, and cases of complaints and challenges for these two classifications of rights have also been found.

In the case of complaints and lawsuits to obtain the right to justice (justiciability), claims in the field of Civil and Political rights are absolute because they are free of charge, although there are also financing related to the provision of state institutions / organs to facilitate civil and political rights, for example the implementation of general elections the right to vote and be elected; Meanwhile, claims to obtain justice in the field of Civil and Political rights or what is called justiciability of Civil and Political rights are of a limited nature, because there is financing to make it happen, so that it is in accordance with the state's ability to fulfill them.

Fulfillment of the justifiability of the ESC rights is also related to the definition of human rights violations, because the claim for the justifiability of the ESC rights is caused by human rights violations. So it is necessary to review legal accountability for these human rights violations. Based on research conducted by Jayadi on four laws concerning the Composition and Position of the People's Consultative Assembly, House of people's representatives and Assembly at provincial that were in effect during President Soeharto in power (namely Law Number 16 of 1969, Law Number 5 of 1975 , Law No. 2 of 1985 and Law No. 5 of 1995), it turns out that none of the material contained in the law regulates which subject should be legally responsible in cases of laws whose material discriminatory. Nor were there any material contents regulating the legal liability procedure. [11]

Related to the field of criminal law, Muladi and Dwidja Priyatno's research found 19 laws and regulations that place corporations as subjects of criminal law, consisting of 17 in the form of laws and two in the form of government regulations. However, the legal liability of the corporation or legal entity that is most likely to be given to the corporation is a fine or additional punishment in the form of revocation of certain rights, confiscation of certain items, or announcement of a judge's decision. Whereas the State is a legal entity, then by using the extensive method of interpretation, the state, to be precise is a state organ, can also be the subject of a criminal act. [11]

New problems arise when corporations commit crimes categorized as gross human rights violations, such as crimes against humanity, genocide, and war crimes. This is because neither the Rome Statute nor Law Number 26 of 2000 concerning Human Rights Courts does not recognize corporations as the subject of offenses. These two legal instruments only recognize individual criminal responsibility, not corporate criminal responsibility, as stipulated in Article 1 point 4 of the Human Rights Court Law, "Everyone is an individual, a group of people, both civilian and military. , as well as the police who are individually responsible ". If those who are subject to criminal responsibility are individuals, not the (state) corporations that are responsible, then efforts to remedy victims of gross human rights violations cannot be fulfilled.

The existence of Law Number 26 of 2000 concerning Human Rights Courts is only to resolve gross human rights violations, so that the scope of human rights violations in the Human Rights Court Law only focuses on gross human rights violations including crimes of genocide and crimes against humanity (Article 7 of the Human Rights Court Law). In Indonesia, there is no court that seeks remedies for victims of human rights violations as a 
form of legal responsibility for legal consequences caused by laws that violate human rights.

On the other hand, in the Human Rights Law, there is an institution that has the authority in the field of human rights, namely the National Human Rights Commission. Article 75 of the Human Rights Law states the objectives for establishing a National Human Rights Commission, namely:

\begin{abstract}
"The national human rights commission aims to: (a) develop conducive conditions for the implementation of human rights in accordance with Pancasila, the 1945 Constitution, and the Charter of the United Nations, as well as the Universal Declaration of Human Rights; and (b) enhancing the protection and enforcement of human rights in order to develop the whole Indonesian human person and his ability to participate in various fields of life.
\end{abstract}

Furthermore, Article 76 paragraph (1) states that "To achieve its objectives, the National Human Rights Commission carries out the functions of study, research, counseling, monitoring and mediation on human rights." Regarding the implementation of the National Commission on Human Rights functions in terms of monitoring, it is regulated in Article 89 paragraph (3) of the Human Rights Law,

"To carry out the functions of the National Human Rights Commission in monitoring as referred to in Article 76, the National Commission on Human Rights has the duty and authority to carry out, among other things: investigations and examinations of events that arise in society which, based on their nature or scope, are reasonably suspected of human rights violations."

In The Explanation of Article 89 letter " $b$ " of the Human Rights Law related to monitoring, "What is meant by 'investigation and examination' in the framework of monitoring is the activity of searching for data, information and facts to find out whether or not there is a human rights violation."

Regarding summons of complainants, victims, witnesses, and / or other parties, it is obligatory to comply with the request of the National Human Rights Commission, and if someone who is summoned does not appear before or refuses to give his / her testimony, the National Human Rights Commission can ask the Chief Justice of the Court to fulfill the summons by force. This is regulated in
Article 94 paragraph (1) and paragraph (2) and Article 95 of the Human Rights Law.

In Article 94 paragraph (1) of the Human Rights Law it is stated, "The complainant, victim, witness, and / or other related parties as referred to in Article 89 paragraph (3) letters c and d, must fulfill the request of the National Human Rights Commission"; and Article 94 paragraph (2) of the Human Rights Law states, "If the obligations referred to in paragraph (1) are not fulfilled by other parties concerned, then for them the provisions of Article 95 apply", while Article 95 of the Human Rights Law states,

"If someone who is summoned does not appear to appear or refuses to give his statement, the National Human Rights Commission may ask the Chief Justice of the Court to fulfill the summons by force in accordance with the provisions of the legislation."

The authority of the National Commission on Human Rights above is limited to investigations, there is no authority at the investigation stage. This means that the authority of investigations at National Human Rights Commission is limited to searching for data, information and facts to find out whether or not there are human rights violations, but does not continue to determine or find the alleged perpetrator, in which the subject of human rights violations must be redefined, as in the previous discussion.

Regarding the provisions of investigation and investigation regulated in Criminal Procedure Code. In Article 1 point 2 of the Criminal Procedure Code it is stated,

"Investigation is a series of actions by the investigator in terms and according to the manner stipulated in this law to seek and collect evidence which with this evidence sheds light on the criminal act that has occurred and to find the suspect."

In Article 1 number 5 Criminal Procedure Code it is stated, "An investigation is a series of actions by an investigator to search for and discover an event that is suspected of being a criminal act in order to determine whether or not an investigation can be carried out in a manner regulated by this law."

The authority of the National Commission on Human Rights in carrying out its investigative function can be made possible in the Criminal Procedure Code itself, and also the adoption of investigative powers within the Corruption Eradication Commission. In Article 1 point 1 of the 
Criminal Procedure Code it is stated, "Investigators are state police officers of the Republic of Indonesia or certain civil servant officials who are given special authority by law to carry out investigations", while in Article 1 point 3 of Law No.30 of 2002 on the Eradication Commission Corruption is declared,

"Eradicating corruption is a series of actions to prevent and eradicate criminal acts of corruption through coordination, supervision, monitoring, investigation, investigation, prosecution and examination in court proceedings, with the participation of the public based on the prevailing laws and regulations".

In Article 6 letter $\mathrm{c}$ of the Corruption Eradication Commission Law it is stated, "The Corruption Eradication Commission has the task of carrying out investigations, investigations and prosecutions of criminal acts of corruption"; Article 7 letter b of the Corruption Eradication Commission Law states, "coordinating investigations, investigations and prosecutions of criminal acts of corruption;" Article 8 paragraph (2) of the Corruption Eradication Commission Law states,

"In exercising the powers referred to in paragraph (1) (supervisory duties), the Corruption Eradication Commission has the authority to also take over the investigation or prosecution of perpetrators of criminal acts of corruption that are being carried out by the police or prosecutors.

In Article 8 paragraph (3) of the Corruption Eradication Commission Law it is stated,

"In the event that the Corruption Eradication Commission takes over the investigation or prosecution, the police or the prosecutor's office is obliged to hand over the suspect and all case files along with evidence and other documents required within a maximum period of 14 (fourteen) working days, starting from the date the Corruption Eradication Commission's request is received. ".

Thus, it can be concluded that the function and authority of the National Commission on Human Rights in monitoring can be increased at the stage of investigation in the framework of protecting and fulfilling the justifiability of Economic, Social and Cultural Rights, but so far cases of human rights violations processed by the National Human Rights Commission are cases of gross human rights violations through Human rights courts are regulated in Law No.26 of 2000 on Human Rights Courts, and even then the victims do not receive remedies because the law does not regulate corporations.

Based on this, it is necessary to study possible courts to try human rights violations, so that the next discussion is related to the Constitutional Court. The lawsuit submitted (judicial review) to the Constitutional Court is of an abstract nature, because what is tested is the norm, in which the Constitutional Court's decision is final and binding, so it is different from the lawsuit in courts in general at the Supreme Court which are concrete and individual and the decisions are executive. The authority of the Constitutional Court is regulated in the third amendment to the 1945 Constitution. [21] In Article 24C paragraph (1) of the 1945 Constitution, it is stated that

"The Constitutional Court has the authority to judge at the first and last levels whose decisions are final to examine the law against the Constitution, decide disputes over the authority of state institutions whose authority is granted by the Constitution, decide the dissolution of political parties, and decide on disputes over election results."

The establishment of the Constitutional Court institution is a tremendous breakthrough in the accessibility of fulfilling justice for economic, social and cultural rights (justiciability) for constitutional rights that are violated by law because they are contrary to the 1945 Constitution. detrimental to constitutional rights. The constitutional rights are stated in the Elucidation of Article 51 paragraph (1) of the Constitutional Court Law, "What is meant by constitutional rights are the rights regulated in the 1945 Constitution", even claims related to these constitutional rights can be filed individually, as regulated in Article 51. paragraph (1) of the Constitutional Court Law.

If the authority of the National Human Rights Commission in monitoring, whose function is to carry out investigations, can be elevated to an investigation, the National Human Rights Commission can bring its investigation files to the Constitutional Court, because it is different from the courts in general at the Supreme Court. This can be in the form of a civil lawsuit with the regulatory model for the Indonesian Civil Code regarding acts against the law, so the legal responsibility model is as follows: First, responsibility with an element of error (deliberate or negligent), as regulated in Article 1365 of the Civil Code; second, responsibility with an element of error, particularly negligence, as regulated in Article 1366 of the Civil Code; and 
third, absolute responsibility (without error) in a very limited sense regulated in Article 1367 of the Civil Code. This article in the Civil Code cannot be applied in cases of laws whose content violates human rights, and victims of human rights violations cannot receive remedies as compensation, especially regarding the fulfillment of economic, social and cultural rights in justice.

Another significant difference is that the examination at the Constitutional Court is based on the 1945 Constitution, whereas the Preamble and Articles of the 1945 Constitution explicitly and on average contain human rights content. In the Preamble it is stated,

"... carrying out world order based on independence, eternal peace and social justice ...", and state ideology "... based on the One Godhead, just and civilized humanity, the unity of Indonesia and the people led by wisdom wisdom in Deliberation / representation, as well as by realizing a social justice for all Indonesian people ".

This provision is a form of Indonesia's participation in upholding the values of an international agreement or covenant and a commitment to the state's responsibility to protect its citizens, which in this context is respecting, protecting and fulfilling human rights.

As mentioned in the previous discussion, many judicial reviews are related to violations of economic, social and cultural rights, such as examining legal norms that contain discriminatory content, and are therefore classified as human rights violations. This further emphasizes the need to redefine human rights violations, namely that the subject of human rights violations is the responsibility of corporations or legal entities and the state is a legal entity including in carrying out legislative functions as a legislator and / or state organ to lower government organs as a policy maker, and which where legal norms to policies are included in the causes of human rights violations.

This idea has been discussed in the previous section regarding the Constitutional Court (within the authority of the Constitutional Court) as a human rights court in South Africa, Spain, South Korea, Azerbaijan, Bavaria and Croatia; whereas there are countries that do not have a Constitutional Court, the judicial system is only in the Supreme Court, for example the United States, Canada and Japan, although there is no Constitutional Court but allegations of human rights violations even until remedial decisions fall under the authority of the Supreme Court. In the Indonesian constitution, the human rights court mechanism is more inclined towards a constitutional court which is under the authority of the Constitutional Court.

Referring to the above discussion, several things can be seen, namely first, the human rights provisions contained in the 1945 Constitution. Although the 1945 Constitution of the Republic of Indonesia is not an operational law, it is clearly visible (explicit) on the mandate or order that is the reference for each law. - An invitation to realize human rights as a form of participation in the international world and the responsibility of the state to its citizens in the field of human rights, particularly in relation to the need for justification of economic, social and cultural rights. Second, human rights are a constitutional right. Third, the application of a constitutional court in South Africa, so that the authority of the institution can be adopted through the Constitutional Court in Indonesia, so that the authority of the Constitutional Court is broader, not only testing norms but also judging legal accountability, not just criminal liability, but civil legal accountability, even lighter than that is administrative legal responsibility. Fourth, this legal accountability is an effort to improve (remedy) in the context of the state's responsibility to respect, protect and fulfill economic, social and cultural rights in justice.

\section{CONCLUSION}

Based on the above discussion, in Indonesia there is no court that has the authority to specifically adjudicate human rights violations, both civil and political rights as well as economic, social, and cultural rights. Human rights justifiability is partial, namely the serious human rights court is tried in the General Court, the administrative sector is tried at the State Administrative Court, labor is tried at the Industrial Relations Court, and the product of legislation is tested under statutory law in the Supreme Court, while judicial review -Invited by the constitution to be tried in the Constitutional Court.

Human rights justifiability in several countries has regulated the provision of remedies, through the Supreme Court, including the United States, Canada, and Japan; and through Constitutional Complaint (Constitutional Complaints) in the Constitutional Court, including South Africa, Germany, Spain, South Korea, Azerbaijan, Bavaria and Croatia. 
The authority of the Constitutional Court in Indonesia is only in the judicial review of legislation products against the constitution, while the examination of statutory regulations under laws is the authority of the Supreme Court. In fact, violations of the constitutional rights of citizens can not only occur through laws, but also through statutory regulations under laws. In addition, the results of the judicial review at the Constitutional Court are abstract in nature, that is, what is tested is the norm, which the decision can invalidate the entire law or part of the law if it conflicts with constitutional rights, and there is no authority to grant remedies.

The results of the discussion show that the concept of human rights justiciability in Indonesia should be tried by the Constitutional Court. This is because, first, human rights are constitutional rights; second, in the 1945 Constitution explicitly provides a mandate or order that becomes the reference for every legislation in order to realize human rights as a form of participation in the international world (international community) and state responsibility for its citizens in the human rights field; thirdly, the Supreme Court cannot grant remedies, because in this Indonesian Civil Code it cannot be applied in cases of laws whose contents violate human rights.

It is highly recommended to build human rights constructions in human rights courts in Indonesia, namely first that the subject of human rights violations in the Human Rights Law needs to be corrected because human rights violations can be caused by the state or government, corporations whether intentional or unintentional or negligence or laws or policies that are written or written in nature. unwritten rights, including in the field of civil and political rights, and / or economic, social and cultural rights. Second, the addition of general provisions in the Human Rights Law regarding human rights justifiability, namely human rights justiciability is an effort made by a person, group of people, or an institution that is competent in the litigation or nonlitigation process, whether in criminal, civil or administrative cases. obtain justice in the civil and political and / or economic, social and cultural fields in order to remedy human rights violations that have occurred. Third, the function and authority of the National Human Rights Commission in monitoring, including mediation, can be enhanced at the investigation stage in the framework of protecting and fulfilling economic, social and cultural rights with justice (justiciability), as defined by the definition of human rights justiciability. Fourth, the authority of the Constitutional Court is proposed to be broader, not only examining norms but also being able to adjudicate legal accountability, not just criminal legal accountability, but also civil legal accountability, even lighter than that, administrative legal accountability in the field of human rights, then a constitutional court is formed. to adjudicate alleged human rights violations and gross human rights violations. These three legal accountabilities are remedial measures in the context of the state's responsibility to respect, protect and fulfill civil and political rights and economic, social and cultural rights in justice.

\section{AUTHORS' CONTRIBUTIONS}

All authors on this paper are main contributors. The three authors have the same contribution in making the paper.

\section{ACKNOWLEDGMENTS}

We would like to thank the Head of the Center for Human Rights Research and Development at The Agency for Research and Development of Law and Human Rights for providing support to the authors. In addition, thanks are also conveyed to the researchers at the Center for Human Rights Research and Development for various suggestions related to the material of this paper.

\section{REFERENCES}

[1] National Human Rights Commission, The 2019 National Commission on Human Rights Report. Jakarta: National Commission on Human Rights, 2020.

[2] Law No. 26 of 2000 concerning Human Rights Courts. Republic of Indonesia, 2000.

[3] Y. A. dan U. R. Rendy Adiwilaga, "Sistem Pemerintahan Indonesia," Yogyakarta: Deepublish, 2018, p. 134.

[4] Mashood A. Baderin, Hukum Internasional HAM dan Hukum Islam. Jakarta: National Human Rights Commission, 2007.

[5] A. Eide, "Hak Ekonomi, Sosial dan Budaya Sebagai Hak Asasi Manusia," in Asbjorn Eide, Catarina Karause, dan Allan Rosas (ed.), Hak Ekonomi, Sosial dan Budaya: Buku Teks Edisi Kedua, Martinus Nijhoff Publisher, 2001, p. 27.

[6] B. A. Garner, Ed., Black's Law Dictionary. St. Paul: St. Paul, West Publishing Co, 1999. 
[7] Yustina Niken Sharaningtyas, "Gugatan Warga Negara (Citizen Law Suit) dan Justiciability Pemenuhan Hak atas Lingkungan Hidup Yang Baik dan Sehat," J. Ilm. Fak. Ilmu Huk. Univ. Udayana "Kertha Patrika," vol. 38, no. Nomor 1, Januari-April 2016, p. 42, 2016.

[8] Soerjono Soekanto \& Sri Mamudji, Penelitian Hukum Normatif: Suatu Tinjauan Singkat. Jakarta: PT. Raja Grafindo Persada, 2003.

[9] Okky Cahyo Nugroho (et.al), Justisiabilitas Hak Ekosob Dalam Penegakan Hak Asasi Manusia. Jakarta: Balitbangkumham Press, 2018.

[10] National Commission on Human Rights, Komentar Umum Kovenan Internasional: Hak Sipil dan Politik, Hak- Ekonomi, Sosial dan Budaya. National Commission on Human Rights, 2009.

[11] Jayadi Damanik, "Pertanggungjawaban Hukum atas Pelanggaran HAM melalui Undang-Undang yang Diskriminatif di Indonesia pada Era Soeharto," Bayumedia Publishing, Bandung, 2008.

[12] Frank Iacobucci, "Judicial Review by The Supreme Court of Canada Under The Canadian Charter of Rights and Freedoms: The First Ten Years," in David M. Beatty (ed.), Human Rights and Judicial Review: A Comparative Prespective, Netherlands: Martinus Nijhoff Publisher, 1994, p. 93.

[13] Itsuo Sonobe, "Human Rights and Constitutional Review in Japan," in on David M. Beatty (ed.), Human Rights and Judicial Review: A Comparative Prespective, Martinus Nijhoff Publisher, 1994, p. 137.

[14] Karth Harper, The Law Handbook, Fitzroy Legal Service. Malang: Bayumedia Publishing, 2008.

[15] Jimly Asshiddiqie, Model-model Pengujian Konstitusional di Berbagai Negara. Malang: Bayumedia Publishing, 2008.

[16] Hukumonline.com, "Menggagas Constitutional Complaint Lewat Kasus Ahmadiyah," 19 Mei 2008.

[17] I Dewa Gede Palguna, “Terlepas' dari Kewenangan Mahkamah Konstitusi RI: Pengaduan Konstitusional (constitutional complaint)," J. Lex Jurnalica, vol. 3, no. No. 3, p. 128.

[18] Sandra Liebenberg, "Perlindungan Hak Ekonomi dan Sosial dalam Sistem Hukum Domestik," in Asbjorn Eide, Catarina Karause, dan Allan Rosas (ed.), Hak Ekonomi, Sosial dan Budaya: Buku Teks Edisi Kedua, Martinus Nijhoff Publisher, 2001, p. 67.

[19] A. Patra M. Zen, "Justisiabilitas Hak-hak Ekonomi, Sosial dan Budaya: Menarik Pengalaman Internasional, Mempraktikannya di Indonesia," J. HAM, Komnas HAM, vol. 1, no. No. 1, p. 42, 2003.

[20] Erna Dyah Kusumawati, "Justiciability of Economic and Social Rights in Indonesia: The Importance of Ratifying the Optional Protocol to the International Covenant on Economic, Social, and Cultural Rights (ICESCR)," J. Huk., vol. 01, no. No. 2, p. 349, 2014.

[21] The Constitution of the Republic of Indonesia of 1945. Republic of Indonesia, 1945. 